\title{
KORELASI ANTARA KEMAMPUAN KOMUNIKASI MATEMATIKA DAN PEMECAHAN MASALAHDENGAN TEKNIK POLYADENGAN HASIL BELAJAR SISWA KELAS VIIMTs USB SAGULUNG BATAM TAHUN PELAJARAN2013/2014
}

\author{
Wati Ritonga ${ }^{1}$ dan Yudhi Hanggara ${ }^{2}$ \\ ${ }^{1}$ Alumni Program Studi Pendidikan Matematika UNRIKA Batam \\ ${ }^{2}$ Dosen Program Studi Pendidikan Matematika Unrika Batam, E-mail: \\ yudhihanggara@gmail.com
}

\begin{abstract}
ABSTRAK
Penelitian ini bertujuan untuk mengetahui ada tidaknya hubungan antara kemampuan komunikasi matematika dan pemecahan masalah dengan teknik polya dengan hasil belajar matematika siswa kelas VII MTs USB Sagulung Batam Tahun Pelajaran 2013/2014. Populasi pada penelitian ini adalah siswa kelas VII dan sampelnya adalah siswa kelas VII yang berjumlah 96 siswa. Instrument yang digunakan dalam penelitian ini adalah instrument tes berbentuk pilihan ganda. Sebelum dipergunakan untuk mengambil data responden dilakukan uji validitas dan reabilitas. Uji persyaratan analisis dilakukan dengan uji normalitas dengan menggunakan uji chi kuadrat. Dari hasil perhitungan diperoleh bahwa data berdistribusi normal. Uji hipotesis dilakukan dengan menggunakan uji korelasi ganda. Berdasarkan hasil penelitian diperoleh sebesar 1,9 dan $F_{\text {tabel }}$ sebesar 3,09. Sehingga dapat disimpulkan bahwa tidak terdapat hubungan yang signifikan antara kemampuan komunikasi matematika dan pemecahan masalah dengan teknik Polya secara bersama-sama terhadap hasil belajar matematika siswa VII MTs USB Sagulung Batam Tahun Pelajaran 2013/2014.
\end{abstract}

Kata kunci : kemampuan komunikasi matematika, pemecahan masalah dengan teknik Polya, hasil belajar matematika

\section{PENDAHULUAN}

Pendidikan merupakan sarana penting untuk meningkatkan kualitas sumber daya manusia (SDM) dalam menjamin keberlangsungan pembangunan suatu bangsa. Pendidikan memegang peran penting dalam mempersiapkan sumber daya manusia yang berkualitas, oleh karena itu pendidikan harus dikelola dengan baik untuk menghasilkan mutu pendidikan yang berkualitas. Peningkatan kualitas sumber daya manusia jauh lebih mendesak untuk segera direalisasikan terutama dalam menghadapi era persaingan global. Oleh karena itu peningkatan kualitas sumber daya manusia sejak dini merupakan hal penting yang harus dipikirkan secara sungguh-sungguh

Matematika merupakan salah satu bidang studi yang ada pada semua jenjang pendidikan, mulai dari tingkat sekolah dasar hingga perguruan tinggi, bahkan matematika di 
ajarkan di Taman kanak-kanak secara informal. Matematika merupakan suatu cara untuk menemukan jawaban terhadap masalah yang di hadapi manusia, suatu cara menggunakan informasi, menggunakan pengetahuan tentang bentuk dan ukuran, serta menggunakan pengetahuan tentang menghitung.

Berdasarkan observasi yang dilakukan penulis pada saat melaksanakan Program Pengalaman Lapangan (PPL). Matematika merupakan mata pelajaran yang kurang diminati oleh sebagian siswa, tidak sedikit siswa yang menyatakan bahwa matematika merupakan mata pelajaran yang sulit dan susah dipahami. Hal ini dapat dilihat ketika guru sedang mengajar siswa sering kali acuh tak acuh terhadap pelajaran dan keluar kelas dengan berbagai alasan. Dalam pendidikan guru memiliki peranan yang sangat penting dalam kegiatan pembelajaran. Guru juga sangat berperan dalam membantu perkembangan siswa untuk mewujudkan tujuan dalam hidupnya secara optimal. Hal ini guru memiliki peranan untuk menanamkan rasa cinta dalam diri siswa terhadap pelajarannya khususnya pelajaran matematika, dimana siswa mempunyai pandangan yang berbeda-beda bahwa guru pelajaran matematika itu pemarah sehingga mengurangi minat belajar siswa.

Proses pembelajaran matematika sangat diperlukan komunikasi antara guru dan siswa. Komunikasi merupakan keterampilan yang sangat penting dalam pembelajaran antara siswa dan guru, tanpa adanya komunikasi yang baik antara guru dan siswa mustahil proses pembelajaran akan baik. Pada umumnya pembelajaran matematika yang dilakukan guru kepada siswa dengan tujuan guru lebih berusaha agar siswa dapat mengerti dan menjawab soal yang diberikan guru, tetapi siswa jarang sekali dimintai penjelasan tentang asal mula mereka mendapat jawaban tersebut dan siswa terkadang takut untuk bertanya, mengeluarkan ide atau pendapat mereka sehingga kemampuan komunikasi siswa kurang atau jarang mendapat perhatian.

Pembelajaran matematika guru telah merancang pembelajaran dengan berbagai pendekatan atau strategi dan metode belajar, namun hasil belajar matematika siswa masih rendah, hal ini dapat dilihat dari hasil ulangan semester ganjil, banyak dari siswa mendapat nilai pas batas Kriteria Ketuntasan Minimal (KKM) bahkan ada siswa mendapat hasil belajar di bawah rata-rata minimal yang dipersyaratkan.

Berdasarkan uraian di atas, maka dapat dirumuskan permasalahan apakah ada hubungan yang signifikan antara kemampuan komunikasi matematika dan pemecahan masalah dengan teknik Polya secara bersama-sama terhadap hasil belajar pada siswa kelas VII MTs USB Sagulung Batam tahun pelajaran 2013/2014 ? 
Tujuan penelitian ini adalah untuk mengetahui apakah terdapat hubungan yang signifikan antara kemampuan komunikasi matematika dan pemecahan masalah dengan teknik Polya secara bersama-sama terhadap hasil belajar pada siswa kelas VII MTs USB Sagulung Batam tahun pelajaran 2013/2014.

\section{LANDASAN TEORI}

Belajar merupakan kegiatan berproses dan merupakan unsur yang sangat penting dalam setiap jenjang pendidikan. Dari keseluruhan proses pendidikan, kegiatan belajar merupakan kegiatan yang paling pokok dan penting dalam keseluruhan proses pendidikan. Belajar adalah proses atau usaha yang dilakukan tiap individu untuk memperoleh suatu perubahan tingkah laku baik dalam bentuk pengetahuan, keterampilan maupun sikap dan nilai yang positif sebagai pengalaman untuk mendapatkan sejumlah kesan dari bahan yang telah dipelajari. Kegiatan belajar tersebut ada yang dilakukan di sekolah, di rumah, dan di tempat lain dan dimana saja. Belajar merupakan tindakan dan perilaku siswa yang kompleks. Sebagai tindakan maka belajar hanya dialami oleh siswa sendiri dan akan menjadi penentu terjadinya atau tidak terjadinya proses belajar.

Hasil belajar adalah angka yang diperoleh siswa yang telah berhasil menuntaskan konsep-konsep mata pelajaran sesuai dengan Kriteria Ketuntasan Minimal (KKM) yang ditetapkan sesuai dengan kurikulum yang berlaku. Begitu juga hasil belajar dapat diartikan sebagai perubahan tingkah laku yang tetap sebagai hasil proses pembelajaran.

Menurut Susanto (2013) bahwa hasil belajar yaitu perubahan yang terjadi pada diri siswa, baik yang menyangkut aspek kognitif, efektif, dan psikomotor sebagai hasil dari kegiatan belajar. Secara sederhana, yang dimaksud dengan hasil belajar siswa adalah kemampuan yang diperoleh anak setelah melalui kegiatan belajar. Belajar itu sendiri merupakan suatu proses dari seseorang yang berusaha untuk memperoleh suatu bentuk perubahan perilaku yang relatif menetap. Dari kegiatan pembelajaran, biasanya guru menetapkan tujuan belajar. Anak yang berhasil dalam belajar adalah yang mencapai tujuan pembelajaran

Menurut Gagne, 1985 cit Sutikno, 2013, ada lima macam hasil belajar, sebagai berikut :

1. Keterampilan intelektual atau keterampilan prosedural yang mencakup belajar konsep, prinsip, dan pemecahan masalah yang kesemuanya diperoleh melalui materi yang disajikan oleh guru di sekolah. 
2. Strategi kognitif, yaitu kemampuan untuk memecahkan masalah baru dengan jalan mengatur proses internal masing-masing individu dalam memperhatikan, mengingat, dan berpikir.

3. Informasi verbal, yaitu kemampuan untuk mendeskripsikan sesuatu dengan kata-kata dengan jalan mengatur informasi yang relevan.

4. Keterampilan motorik, yaitu kemampuan untuk melaksanakan dan mengkoordinasikan gerakan yang berhubungan dengan otot.

Sikap, yaitu suatu kemampuan internal yang mempengaruhi tingkah laku seseorang didasari oleh emosi, kepercayaan, serta faktor intelektual

\section{A. Kemampuan komunikasi matematika}

Komunikasi secara umum dapat diartikan sebagai suatu cara untuk menyampaikan pesan ke penerima pesan untuk memberitahu, pendapat, atau perilaku baik langsung secara lisan maupun tak langsung melalui media. Di dalam berkomunikasi tersebut harus dipikirkan bagaimana caranya agar pesan yang disampaikan seseorang itu dapat dipahami orang lain. Menurut Iriantara (2013) bahwa komunikasi sebagai proses penyampaian pesan kepada penerima pesan dengan tujuan tertentu.

Kemampuan komunikasi matematika menjadi penting ketika diskusi antar siswa dilakukan, di mana siswa diharapkan mampu menyatakan, menjelaskan, menggambarkan, mendengar, menanyakan, dan bekerja sama sehingga dapat membawa siswa pada pemahaman yang mendalam tentang matematika. Hal ini, kemampuan komunikasi dipandang sebagai kemampuan siswa mengkomunikasikan matematika yang dipelajari sebagai isi pesan yang harus disampaikan. Dengan siswa mengkomunikasikan pengetahuan yang dimilikinya, maka dapat terjadi respon antar siswa. Selain itu, kemampuan komunikasi matematika itu juga penting dimiliki oleh siswa dengan beberapa alasan mendasar yaitu :

1. Kemampuan komunikasi matematika menjadi kekuatan sentral bagi siswa dalam merumuskan konsep dan strategi.

2. Kemampuan komunikasi matematika sebagai modal keberhasilan bagi siswa terhadap pendekatan dan penyelesaian dalam matematika.

3. Kemampuan komunikasi matematika sebagai wadah bagi siswa dalam berkomunikasi dengan temannya untuk memperoleh informasi dan berbagai pikiran.

Beberapa kriteria yang dipakai dalam melihat seberapa kemampuan siswa dalam memiliki kemampuan matematika pada pembelajaran matematika adalah sebagaimana yang dikemukakan oleh NCTM, 1989, cit. Susanto, 2013, sebagai berikut: 
1. Kemampuan mengekspresikan ide-ide matematika melalui lisan, tulisan, dan mendemonstrasikannya serta menggambarkannya secara visual.

2. Kemampuan memahami, menginterpresikan, dan mengevaluasi ide-ide matematika baik secara lisan maupun dalam bentuk visual lainnya.

3. Kemampuan menggunakan istilah, notasi matematika dan struktur-strukturnya untuk menyajikan ide, menggambarkan hubungan dan model situasi.

\section{B. Komunikasi dalam proses pembelajaran}

Ada tiga pola komunikasi yang dapat digunakan untuk mengembangkan interaksi dinamis antara guru dengan siswa menurut Sudjana, 1989, cit. Sutikno, 2013 yaitu:

1. Komunikasi sebagai aksi atau komunikasi satu arah. Maka komunikasi ini, guru berperan sebagai pemberi aksi dan siswa sebagai penerima aksi.

2. Komunikasi sebagai interaksi atau komunikasi dua arah. Pada komunikasi ini guru dan siswa dapat berperan sama yaitu pemberi aksi dan penerima aksi.

3. Komunikasi banyak arah atau komunikasi sebagai transaksi. Komunikasi ini tidak hanya melibatkan interaksi dinamis antara guru dengan siswa tetapi juga melibatkan interaksi dinamis antara siswa yang satu dengan siswa yang lainnya. Proses pembelajaran dengan pola komunikasi ini mengarah kepada proses pembelajaran yang mengembangkan kegiatan siswa yang optimal, sehingga menumbuhkan siswa belajar aktif.

\section{Pemecahan Masalah Dengan Teknik Polya}

Pemecahan masalah merupakan suatu cara belajar yang dianggap sangat efisien dalam usaha untuk mencapai tujuan pengajaran. proses belajar melalui pemecahan masalah bertolak dari pandangan bahwa siswa sebagai subjek dan objek dalam belajar yang mempunyai kemampuan untuk memecahkan masalah pada dasarnya merupakan tujuan pendidikan, siswa dituntut untuk menjawab pertanyaan-pertanyaan atau memecahkan masalah mereka sehingga siswa termotivasi untuk belajar keras.

\section{Langkah-langkah penyelesaian masalah menurut Polya.}

Pada pembelajaran pemecahan masalah, guru harus dapat membangkitkan minat siswa untuk terlibat dalam pemecahan masalah yang diajukan. Guru membimbing siswa secara bertahap agar siswa dapat menemukan solusi masalah yang diajukan.Polya 1985, cit. Susanto, 2013, menyebutkan ada empat langkah dalam pembelajaran pemecahan masalah yaitu

1. Memahami masalah 
2. Merencanakan penyelesaian

3. Melalui perhitungan

4. Memeriksa kembali proses dan hasil

\section{METODOLOGI PENELITIAN}

Metode penelitian adalah cara ilmiah untuk mengumpulkan data dengan tujuan dan kegunaan tertentu. Penelitian ini merupakan penelitian kuantitatif dengan jenis penelitian korelasional. Penelitian ini diarahkan untuk menguji hubungan antara dua variabel yaitu kemampuan komunikasi matematika $\left(\mathrm{X}_{1}\right)$, dan pemecahan masalah dengan teknik Polya $\left(\mathrm{X}_{2}\right)$, terhadap hasil belajar matematika siswa (Y), penelitian dilaksanakan pada bulan Mei 2014 sampai dengan Juni 2014. Maka populasi yang diambil dalam penelitian ini adalah siswa di MTs USB Sagulung Batam pada tahun pelajaran 2013/2014. Dalam penelitian ini, teknik pengambilan sampel yang digunakan adalah Probability Sampling dan jenisnya adalah Simple Random Sampling. Maksud dari Probability Sampling menurut Widiyanto (2013) yaitu teknik pengambilan sampel yang memberikan peluang yang sama bagi setiap unsur atau (anggota) populasi untuk dipilih menjadi anggota sampel. Sedangkan simple random sampling dikatakan simple (sederhana) karena pengambilan anggota sampel dari populasi dilakukan secara acak tanpa memerhatikan strata yang ada dalam populasi itu. Jadi sampel dalam penelitian ini adalah siswa kelas VII di MTs USB Sagulung Batam tahun ajaran 2013/2014.

Pengumpulan data dalam penelitian ini dimaksudkan untuk memperoleh data yang relevan, akurat, dan reliabel. Data yang dikumpulkan dalam penelitian ini digunakan untuk menguji hipotesis atau menjawab pertanyaan yang telah dirumuskan karena data yang diperoleh akan dijadikan landasan dalam mengambil kesimpulan, data yang dikumpulkan haruslah data yang benar. Agar data yang dikumpulkan baik dan benar, instrumen pengumpulan datanya pun harus baik, dalam penelitian ini instrumen pengumpulan datanya berupa angket dan tes.

Instrumen penelitian merupakan alat pengumpulan data yang digunakan dalam suatu penelitian. Untuk memperoleh data tentang kemampuan pemecahan masalah dengan teknik Polya, peneliti menggunakan alat pengumpulan data berupa tes yang berfungsi untuk mengukur kemampuan pemecahan masalah dengan teknik Polya pada individu siswa. Penelitian ini menggunakan instrumen penelitian berupa tes soal berbentuk uraian

\section{Validitas}


Suatu instrumen tes penelitian dikatakan valid apabila dapat mengungkapkan data dari variabel yang diteliti secara tepat ( Arikunto 2013). Instrumen yang valid adalah instrumen yang mengukur apa yang hendak diukur. Hal ini yang ingin diukur kevaliditannya yaitu kemampuan komunikasi matematika dengan menggunakan angket dan pemecahan masalah dengan teknik Polya menggunakan tes berbentuk uraian dengan rumus Product Moment. Adapun rumus Product Moment sebagai berikut :

\section{Reliabilitas}

Reliabilitas instrumen adalah keadaan instrumen yang menunjukkan hasil pengukuran yang reliabel. Instrumen yang reliabel adalah instrumen yang apabila digunakan untuk mengukur subyek dan objek yang sama pada waktu yang berbeda dan pengukuran dilakukan oleh yang berbeda hasilnya tetap sama.

Dimana rumus koefisien reliabilitas Alfa Cronbach sebagai berikutSugiyono (2013) :

Keterangan :

$$
\begin{aligned}
& \mathrm{r}_{11}=\text { Koefisien nilai reliabilitas } \\
& \mathrm{K}=\text { Banyaknya butir item yang valid } \\
& \boldsymbol{\Sigma}=\text { Jumlah varians skor dari tiap-tiap item } \\
& =\text { Varians total }
\end{aligned}
$$

\section{Uji Hipotesis}

Hipotesis yang digunakan adalah hipotesis asosiatif dengan teknik korelasional yang meliputi uji korelasi parsial dan uji korelasi ganda.

Sugiyono (2013) menyatakan korelasi ganda merupakan angka yang menunjukkan arah dan kuatnya hubungan dua variabel independen secara bersama-sama atau lebih dengan satu variabel dependen. Dalam hal ini dikemukakan korelasi ganda (R) untuk dua variabel independen dan satu dependen adalah kemampuan komunikasi matematika ( $\mathrm{X}_{1)}$, dan pemecahan masalah dengan teknik Polya $\left(\mathrm{X}_{2}\right)$, terhadap hasil belajar matematika siswa $(\mathrm{Y})$. Adapun rumus korelasi ganda sebagai berikut (Riduwan 2011) :

1. Menghitung nilai korelasi $\mathrm{X}_{1}$ terhadap $\mathrm{Y}$. 
2. Menghitung nilai korelasi $\mathrm{X}_{2}$ terhadap $\mathrm{Y}$

3. Menghitung nilai korelasi $\mathrm{X}_{1}$ dan $\mathrm{X}_{2}$

4. Menghitung nilai korelasi $\mathrm{X}_{1}, \mathrm{X}_{2}$ terhadap $\mathrm{Y}$

Keterangan :

= Korelasi antara variabel $\mathrm{X}_{1}$ dengan $\mathrm{X}_{2}$ secara bersama-sama dengan variabel $\mathrm{Y}$

= Korelasi product moment antara $\mathrm{X}_{1}$ dengan $\mathrm{Y}$

$=$ Korelasi product moment antara $\mathrm{X}_{2}$ dengan $\mathrm{Y}$

$=$ Korelasi product moment antara $\mathrm{X}_{1}$ dengan $\mathrm{X}_{2}$

\section{HASIL PENELITIAN DAN PEMBAHASAN}

Penelitian ini bertujuan untuk menguji hubungan antara kemampuan komunikasi matematika dan pemecahan masalah dengan teknik Polya terhadap hasil belajar matematika. Berdasarkan data penelitian yang dianalisa maka dilakukan pembahasan tentang hasil penelitian sebagai berikut :

1. Korelasi antara kemampuan komunikasi matematika terhadap hasil belajar matematika.

Kemampuan komunikasi matematika $\left(\mathrm{X}_{1}\right)$ didapat dari hasil angket yang di uji coba pada siswa kelas VII di MTs USB Sagulung Batam yang telah dipilih untuk menjadi uji coba. Hasil penelitian menunjukkan bahwa tidak terdapat hubungan yang positif dan signifikan antara kemampuan komunikasi matematika terhadap hasil belajar matematika. Hal ini dapat di lihat dari analisis korelasi Product Moment diporeleh nilai koefisien korelasi $=-0,098$ dapat dinyatakan $t_{\text {hitung }}(-0,959)<$ dari $t_{\text {tabel }}(1,66)$, maka korelasi $\mathrm{X}_{1}$ dengan $\mathrm{Y}$ tidak terdapat hubungan yang signifikan. Dari koefisien determinasi $\left(R^{2}\right)$ sebesar $(-0,098)^{2}=0,009$ dan dipersentasikan menjadi $=0,960 \%$ sedangkan sisanya sebesar 99,04\% ditentukan oleh variabel lain yang tidak dibahas dalam penelitian ini.

2. Korelasi antara pemecahan masalah dengan teknik Polya terhadap hasil belajar matematika

Pemecahan asalah dengan teknik Polya $\left(\mathrm{X}_{2}\right)$ didapat dari hasil tes uraian yang di uji coba pada siswa kelas VII di MTs USB Sagulung Batam yang telah dipilih untuk menjadi uji 
coba. Setelah data terkumpul melalui tes uraian dan analisis instrumen pengumpul data mengenai kinerja siswa dalam menyelesaikan masalah ternyata menunjukkan bahwa pemecahan masalah dengan teknik Polya dapat meningkatkan kemampuan siswa dalam memecahkan masalah matematika dengan rincian sebagai berikut:

a. Kemampuan pada aspek menganalisis masalah, ditunjukkan dengan kemampuan siswa dalam menentukan apa yang diketahui , apa yang ditanyakan, dan apa yang diperlukan.

b. Kemampuan dalam merencanakan penyelesaian masalah, ditunjukkan dengan kemampuan menentukan konsep-konsep yang terkait yang mendukung proses pemecahan masalah.

c. Kemampuan melakukan perhitungan sesuai dengan yang direncanakan, hal ini ditunjukkan dengan kemampuan siswa menyelesaikan perhitungan secara sistematis sesuai dengan tahap-tahap yang direncanakan.

d. Kemampuan mengoreksi langkah-langkah penyelesaian yang sudah dilakukan, hal ini ditunjukkan dengan sikap siswa yang meragukan hasil akhir setelah proses perhitungan dan tertuntut untuk mengoreksi kembali langkah-langkah penyelesaian yang saling terkait.

Dengan diterapkannya pemecahan masalah dengan teknik Polya terdapat Hal ini dapat dilihat dari hasil penelitian menunjukkan bahwa terdapat hubungan yang positif dan signifikan antara kemampuan komunikasi matematika terhadap hasil belajar matematika. Hal ini dapat dilihat dari analisis korelasi Product Moment diporeleh nilai koefisien korelasi = 0,230dan diperoleh sebesar 2,290 dengan $\mathrm{n}=94$, taraf signifikan $5 \%$, dan $\mathrm{dk}=2$, maka $t_{\text {tabel }}$ sebesar 1,66. Hal ini menunjukkan bahwa $t_{\text {hitung }}(2,290)>$ dari $t_{\text {tabel }}(1,66)$, maka korelasi $X_{2}$ dengan $\mathrm{Y}$ terdapat hubungan yang signifikan. Dari koefisien determinasi $\left(\mathrm{R}^{2}\right)$ sebesar $(0,230)^{2}=0,0529$ dan dipersentasikan menjadi $=5,29 \%$ sedangkan sisanya sebesar $94,71 \%$ ditentukan oleh variabel lain yang tidak dibahas dalam penelitian ini. Dari hasil penelitian ini dapat disimpulkan bahwa semakin baik cara penyelesaian pemecahan masalah dalam menyelesaikan soal matematika siswa, maka hasil belajar matematika siswa akan semakin tinggi juga.

Korelasi antara kemampuan komunikasi matematika dan pemecahan masalah dengan teknik Polya secara bersama-sama terhadap hasil belajar matematika Hasil analisis dari pengujian hipotesis yang ketiga menunjukkan bahwa tidak terdapat hubungan yang signifikan antara kemampuan komunikasi matematika dan pemecahan 
masalah dengan teknik Polya secara bersama-sama terhadap hasil belajar matematika siswa yang ditunjukkan dengan koefisien korelasi ganda sebesar 0,24 dan diperoleh sebesar 1,9 dengan $\mathrm{n}=94$, dan taraf signifikansi $=5 \%$, dk pembilang $=\mathrm{k}$ sedangkan dk penyebut $=(\mathrm{n}-$ $k$ - 1) maka diperoleh $F_{\text {tabel }}$ sebesar 3,09. Hal ini menunjukkan bahwa harga $F_{\text {tabel }}>$ sehingga dapat disimpulkan bahwa tidak terdapat hubungan yang signifikan antara kemampuan komunikasi matematika dan pemecahan masalah dengan teknik Polya secara bersama-sama terhadap hasil belajar matematika. Dari koefisien determinasi $\left(R^{2}\right)$ sebesar $(0,24)^{2}=0,057$ dan dipersentasikan menjadi 5,76\% sedangkan sisanya sebesar 94,24\% ditentukan oleh variabel lain yang tidak dibahas dalam penelitian ini.

\section{KESIMPULAN DAN SARAN}

\section{a. Kesimpulan}

Berdasarkan data yang diperoleh dari hasil analisis yang dilakukan, maka kesimpulan yang dapat dikemukakan dalam penelitian ini adalah sebagai berikut:

1. Tidak terdapat hubungan yang signifikan antara kemampuan komunikasi matematika terhadap hasil belajar

2. Terdapat hubungan yang positif dan signifikan antara pemecahan masalah dengan teknik Polya terhadap hasil belajar

3. Tidak terdapat hubungan yang signifikan antara kemampuan komunikasi matematika dan pemecahan masalah dengan teknik Polya secara bersama-sama terhadap hasil belajar matematika siswa.

\section{b. Saran}

Berdasarkan penelitian ini, ada beberapa saran sebagai bahan pertimbangan dalam melaksanakan pembelajaran matematika dengan komunikasi matematika dan pemecahan masalah dengan teknik Polya terhadap hasil belajar.

1. Pembelajaran pemecahan masalah dengan teknik Polya membutuhkan waktu yang relatif banyak, sehingga penggunaan alokasi waktu harus benar-benar diperhitungkan agar pelaksanaan pembelajaran dapat berjalan secara optimal.

2. Komunikasi matematika dapat digunakan sebagai salah satu variasi dalam pembelajaran matematika karena dengan menggunakan komunikasi matematika ini siswa dapat terlibat secara aktif dan dapat menimbulkan motivasi belajar sehingga dapat lebih memahami konsep. 


\section{Daftar Pustaka}

Arikunto, S. 2013. Prosedur Penelitian Suatu Pendekatan Praktik. Jakarta : PT Rineka Cipta Iriantara, Y dan Usep. 2013. Komunikasi Pendidikan. Bandung : Simbiosa Rekatama Media Riduwan 2011. Dasar-dasar Statistika. Bandung: Alfabeta

Susanto, A. 2013. Teori Belajar dan Pembelajaran di Sekolah Dasar. Jakarta : Kencana Prenada Media Group

Sugiyono 2013. Statistik Pendidikan. Bandung : Alfabeta

Sutikno, S. 2013. Belajar dan Pembelajaran “ Upaya Kreatif dalam Mewujudkan Pembelajaran yang Berhasil. Lombok : Holistica

Widiyanto, M (2013). Statistika Terapan : Konsep dan Aplikasi SPSS dalam Penelitian Bidang Pendidikan, Psikologi dan Ilmu Sosial Lainnya. Jakarta : PT Elek Media Komputindo. 